\title{
O ofício de viver, \\ o ofício de ensinar, \\ o ofício de escrever
}

Entrevista de Norberto Bobbio a Petro Polito

\section{Elogio do diálogo}

$\mathrm{P}$ ETRO POLITO - Prezado professor, antes de tudo, the agradeço por ter aceitado a idéia de darmos continuidade ao nosso Dialogo de alguns anos atrás ${ }^{1}$ Espero que esta seja uma nova ocasião para uma "conversa amigável” que satisfaça os dois dialogadores "já pelo prazer que transmite". Em um diálogo com Antonio Gnoli e Franco Volpi, assim Ernst Jünger define "a melhor forma da entrevista". Pois bem, se eu tivesse que dizer qualé o feitio dominante do seu caráter, não teria dúvida em indicar a propensão, ou talvez, a vocação ao diálogo.

Norberto Bobbio - Para nós que saímos da Segunda Guerra Mundial, que durou por cinco anos, o diálogo, mais que uma vocação, foi uma necessidade. $\mathrm{Na}$ guerra o outro é o inimigo. Com o inimigo não se dialoga, mas se combate para vencê-lo, vale dizer, para não lhe dar mais a possibilidade de falar. A primeira condição para que o diálogo seja possível é o respeito recíproco, que pressupõe o dever de compreender lealmente aquilo que o outro diz e, mesmo que não se esteja de acordo, procura-se contestá-lo sem animosidades, expondo argumentos prós e contras. Se o diálogo se interrompe por não conduzir a um acordo, não há nada de mal. Pode-se retornar a ele em um outro momento. O diálogo é sempre um discurso de paz e não de guerra. Temos todos, nestes dias, à nossa frente, uma situação na qual o confronto armado começou quando o diálogo não era mais possível. ${ }^{3}$ Nenhuma prova é melhor sobre o fato de que diálogo e confronto são termos antiéticos: o diálogo somente pode iniciar quando o confronto termina, o confronto começa quando o diálogo não é mais possível.

Petro Polito - Por outro lado, você escreven muito sobre o diálogo.

Norberto Bobbio - Sim. O que estou dizendo não é uma novidade. Em verdade, sobre o método do diálogo contraposto àquele da discórdia, por algumas vezes, discorri em meus escritos e, em particular, nos escritos sobre a paz e a guerra que você agrupou no terceiro volume de Il terzo assente (1989). Refiro-me, por exemplo, ao discurso Etica della potenza ed etica del dialogo, que compreende algumas páginas intituladas Ristabilive la fiducia nel dialogo, onde escrevo: "A ética do diálogo se contrapõe à ética da potência. Compreensão contra prepotência. Respeito ao outro como sujeito contra o rebaixamento do outro a obje- 


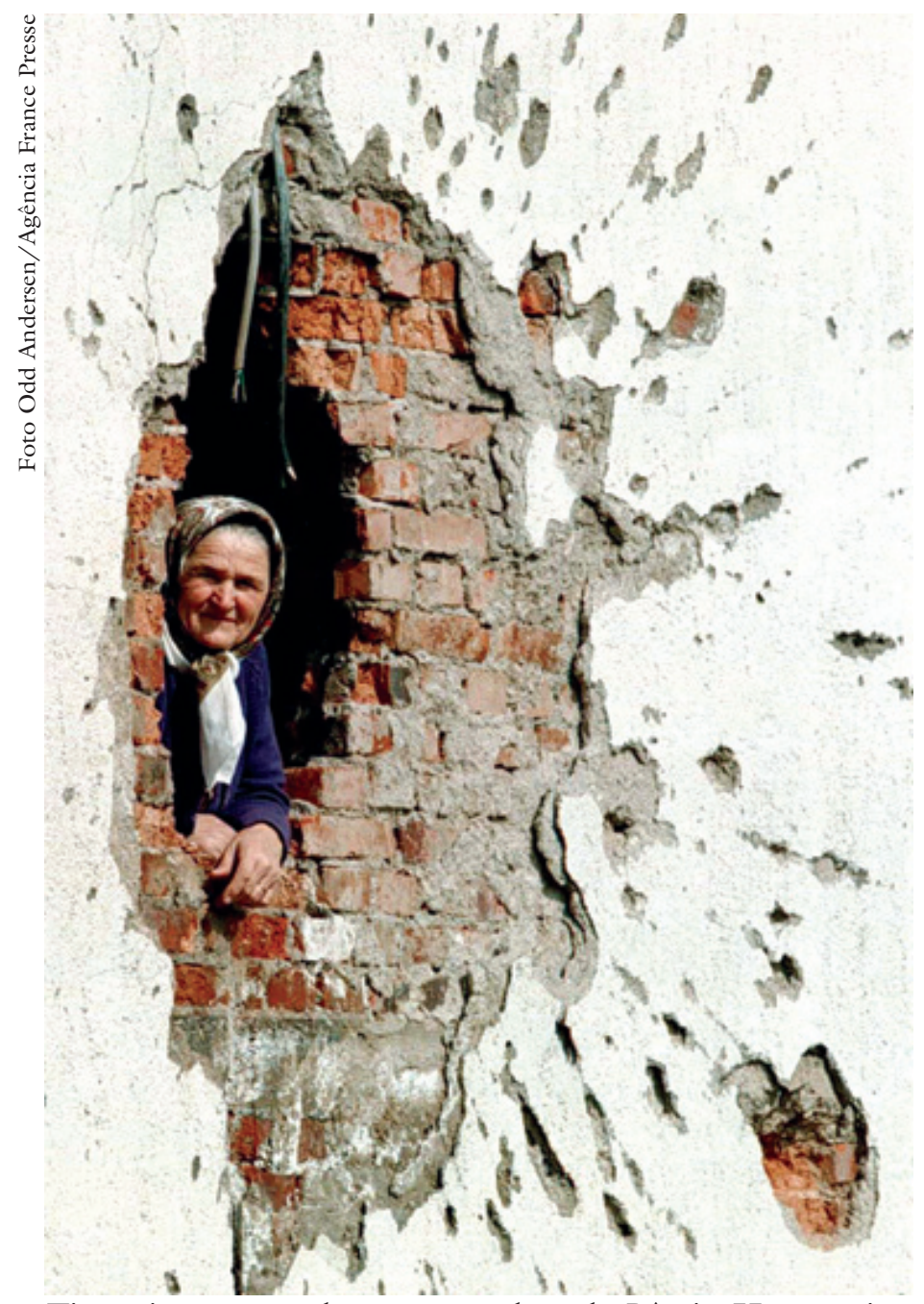

to". ${ }^{4}$ Reporto-me a isso também em um outro discurso, Il dialogo per la pace, no qual incluo: "Para dialogar não basta falarmos, trocarmos palavras. Até mesmo os potentes deste mundo falam entre si, mas quase sempre cada um fala por si mesmo ou pelos próprios amigos. Dois monólogos não constroem um diálogo". ${ }^{5}$ Por último, falei também na introdução ao De senectute, intitulada A me stesso: "Pode-se servir da palavra para esconder as próprias intenções mais do que para manifestá-las, para enganar o adversário em vez de convencê-lo. Não somente fiz o elogio do diálogo, mas pratiqueio por muito tempo". ${ }^{6}$

Tiro atinge a casa de uma moradora da Bósnia-Herzegovina.

Petro Polito - Não faltaram ocasiões, a começar pelos primeiros anos depois da guerra.

Norberto Bobbio - Você tem razão. Logo após a guerra, que parecia tivesse aberto um diálogo não somente dentro dos estados democráticos, mas mesmo entre um e outro estado, o diálogo foi logo interrompido entre a Europa do Ocidente e a Europa do Oriente. Entre uma e outra se ergueu o que então era chamado a cortina de ferro. Para que o diálogo seja interrompido não é necessário que se exploda o confronto, basta que entre os dois potenciais falantes a comunicação se torne impossível. A partir de 1951 participei ativamente nas ações da Sociedade Européia de Cultura que, fundada um ano antes por Umberto Campagnolo, havia se proposto a reunir intelectuais de uma e de outra parte da Europa para ultrapassar, em nome da "política da cultura", as proibições impostas pela "política dos políticos". Muitas das minhas participações como membro dessa Sociedade, entre 1951 e 1955, reunidas no livro Politica e cultura (1955), são dedicadas, na maioria das vezes, a um diálogo sereno, leal, respeitoso, sem deixar de ser convincente, 
mesmo nos momentos em que o diálogo parecia, se não interrompido, mais difícil. Na Introduzione escrita em julho de 1955, afirmo "que o dever do homem de cultura" era, e esta me parece uma condição significativa, "de restabelecer a confiança no colóquio" e que o melhor modo de não o interromper "fosse aquele de começar a dar o bom exemplo". Os ensaios reunidos, de fato, tinham por objetivo o diálogo e são estes mesmos, quase todos os diálogos, "exercícios de testemunho do particular comportamento mental ou disposição espiritual que os provocou".?

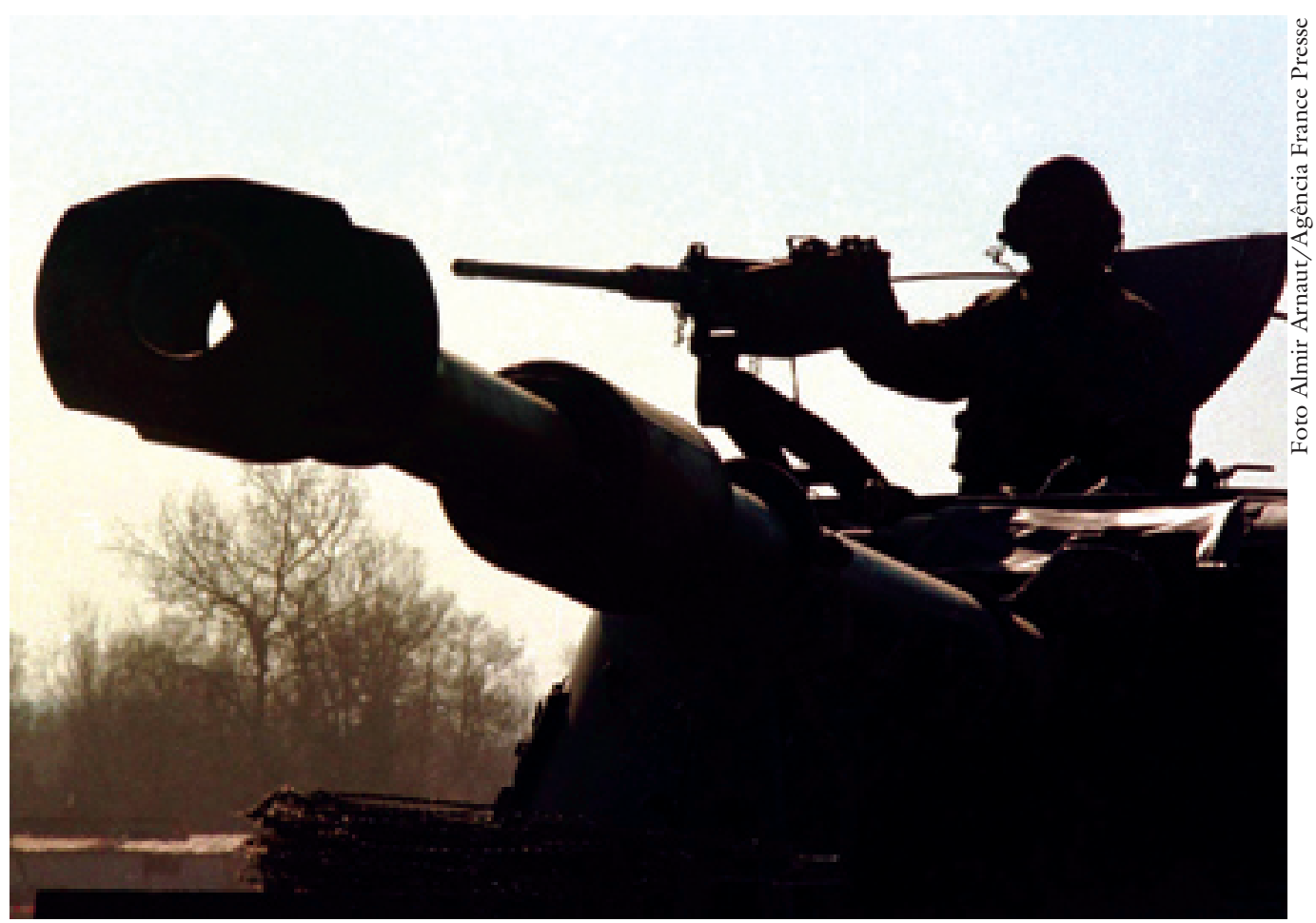

Soldado faz patrulha com tanque na região de conflito na Bósnia-Herzegovina.

Petro Polito - Sobre o diálogo foram escritas páginas famosas. Seu amigo Campagnolo, que você definiu como "um homem do diálogo", dedica ao diálogo um capitulo inteiro no Petit dictionnaire pour une politique de la culture. ${ }^{8}$

Norberto Bobbio - Sempre levei em consideração esse apelo de Campagnolo ao diálogo, tanto que, como diretor da revista Comprendre, em um dos últimos números publicados no início dos anos 1980 e dedicado ao tema Violenza $e$ dialogo, retomei uma de suas manifestações mais significativas: "O diálogo mostra-se hoje, mais do que nunca, necessário. Aos homens, na impossibilidade de se ignorarem em um planeta que se tornou pequeno na medida dos seus conhecimentos e das suas técnicas, não é possível outra escolha que não seja entre o diálogo e a violência. O dilema é claro: a conversa ou o combate". ${ }^{9}$

\section{As leituras da formação}

Petro Polito - Você dedica muito do seu tempo à leitura. E sei que você lê à noite. Foi sempre assim? Faça uma distinção entre leitura de trabalho e outras leituras? 
Norberto Bobbio - Eu sempre li muito, embora não tenha sido um leitor precoce. Quando jovem eu li pouco. Não fui um voraz devorador de livros como meu irmão. Na época, o autor mais querido era Salgari. Dos livros de Salgari, comparando-me ao meu irmão e a outros colegas, eu li dois ou três apenas. Lembro-me de um dos menos conhecidos, Uma sfida al polo. Imagine que o mais célebre dos seus romances, Il corsaro nero, eu li por curiosidade alguns meses atrás, quando as senhoras Viglongo, amigas de longa data, me enviaram a cópia anastática do livro, no centenário da primeira edição. Iniciei a me tornar um apaixonado leitor de livros de qualquer gênero quando já estava no liceo. ${ }^{10}$ Mas nunca fui, e talvez tenha me tornado com os anos e com a obstinação do leitor profissional, um leitor rápido. Tanto que fui surpreendido, quando numa entrevista pública feita por Beniamino Placido no Salão do Livro de 1995, uma das perguntas foi sobre as minhas leituras juvenis, tomei em mãos uma agenda de 1928 onde eu assinalava mês a mês as leituras feitas e enunciei, ao acaso, o mês de dezembro onde apareciam dezoito livros dos mais desbaratados, que iam de um romance de Giovanni Battista Angioletti, intitulado Il giorno del giudizio, aos Elementi della politica de Croce. Entre esses, incrível, La chartreuse de Parme de Stendhal. ${ }^{11}$ A paixão pelos livros não é diminuída, pelo contrário, com todos os livros que recebo a cada dia, a tentação aumentou, tanto que raramente consigo ler um livro do começo ao fim. Inicio muitos e não termino nenhum. Mas agora a leitura tornou-se mais uma distração. São sempre mais raras as leituras a que você se referiu, de trabalho, pois essas nascem principalmente da pesquisa e das aulas, e como já faz anos que não ensino mais, meu empenho é maior em rever pesquisas já feitas do que fazer outras novas.

Petro Polito - Quais as leituras que foram mais marcantes na formação do filósofo?

Norberto Bobbio - Nos anos da formação, certamente as obras de Croce, dentre as quais, as últimas, íamos lendo à medida que eram lançadas e isso era sempre assunto de discussão entre nós. Mais as de Croce do que as de Gentile. Torna-se banal repetir e pode ser, além de surpreendente, até mesmo incompreensível para os jovens de hoje, mas a nossa foi uma geração crociana. Aquilo que havia, na obra de Croce, de tão sugestivo, não é fácil de explicar. Tentei fazê-lo num artigo que escrevi dez anos após a sua morte. Mas sou o primeiro a perceber que as minhas argumentações valem somente para aqueles que tiveram as mesmas experiências que eu e no mesmo contexto histórico em que foram vividas, incomparáveis, é inútil dizer, com os dias de hoje. Nos anos seguintes à maturità, ${ }^{12}$ os autores que me guiaram foram aqueles que contribuíram de maior forma em dar corpo e essência às minhas aulas. Não preciso aqui lembrar que lecionei Teoria do direito, Teoria da política e História do pensamento político e jurídico. Para a teoria do direito, eu diria Kelsen, para a filosofia política, Max Weber. Na história do pensamento político e jurídico, meus autores foram Hobbes, Locke, Kant, Rousseau, Hegel; os meus "clássicos", que por várias vezes eu li e comentei na escola. No que diz respeito a Marx, desde Croce e Gentile 


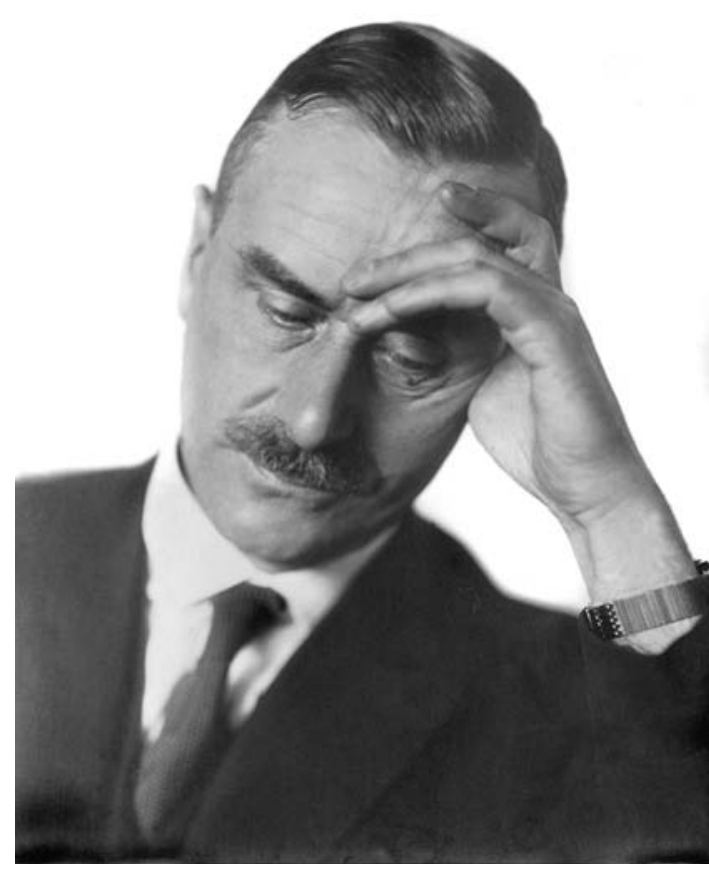

Thomas Mann (1875-1955), escritor alemão.

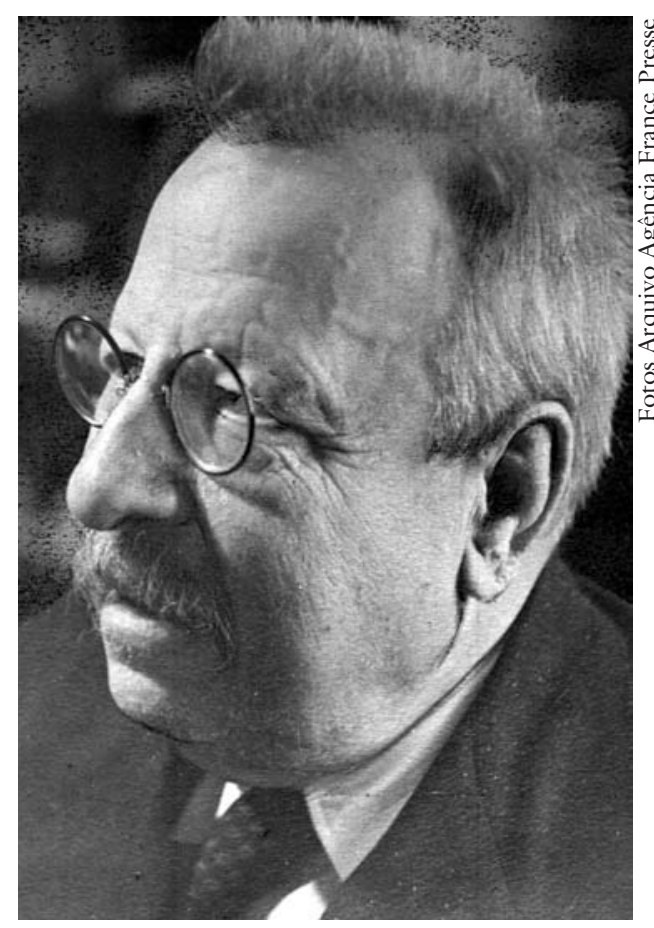

O filósofo Benedetto Croce (1866-1952).

a Mondolfo e até Gramsci, a obra do autor do Capital foi, em nosso país, uma leitura obrigatória, mas nunca a utilizei como objeto de estudo sistemático. ${ }^{13}$

Petro Polito - Na mesma entrevista com Beniamino Placido, você disse que Thomas Mann foi seu escritor preferido. De que maneira? Quando você leu Mann?

Norberto Bobbio - Considero Thomas Mann o maior escritor da primeira metade do século, que foi também a época da minha formação moral e intelectual. Eu o li e reli na minha idade madura. Refiro-me, em particular, aos três romances, Os Buddenbrooks, A montanha mágica e Doutor Fausto, que é o romance da decadência européia por ele vivida dramaticamente, da Primeira à Segunda Guerra Mundial. São belíssimos os tratados sobre alguns grandes espíritos europeus, desde Goethe a Schopenhauer, de Tolstoi a Dostoiévski, reunidos no volume Nobilità dello spirito. As mensagens que ele enviou, quase cotidianamente, pelo rádio dos Estados Unidos, estão entre as páginas que mais veementemente condenaram a Alemanha nazista. "Nobile spirito", Thomas Mann deve ser inserido na galeria de espíritos nobres, por ele criada e ilustrada. ${ }^{14}$

Petro Polito - Numa recente declaração, você disse que o poeta com quem tem mais afinidade é Giacomo Leopardi. Por quê?

Norberto Bobbio - Aquilo que sempre me fascina e, de certa forma, me transtorna quando leio Leopardi, seja em poesia seja em prosa, é o seu ateísmo profundamente religioso, de uma religiosidade sem igreja, sem dogmas e sem ritos. Falo de uma religiosidade que se lança em direção ao mistério, em que se aprofunda a razão humana sem encontrar nem o princípio nem o fim de todas as coisas. O sofrimento de Leopardi, seu pessimismo exaltado ou execrado, deriva 
dessa aspiração não satisfeita em chegar às raízes das coisas. Há alguns versos da curta poesia $A$ me stesso, de cujo encanto nunca consegui me afastar: "...Envolto pelo extremo engano / de eterno me imaginar"; "À nossa espécie, o destino / não reservou senão a morte". O desolado último verso: "E a infinita vaidade do todo". O mesmo encanto reencontrei nas últimas palavras do Cantico del gallo silvestre nas Operette morali: "Virá o tempo em que o universo, e a própria natureza, terminará. De tal modo, que dos grandiosos reinos e impérios humanos e seus maravilhosos levantes, que foram famosos em outras épocas, hoje não perdura nem sinais nem fama alguma; igualmente, do mundo inteiro e das infinitas vicissitudes e calamidades que

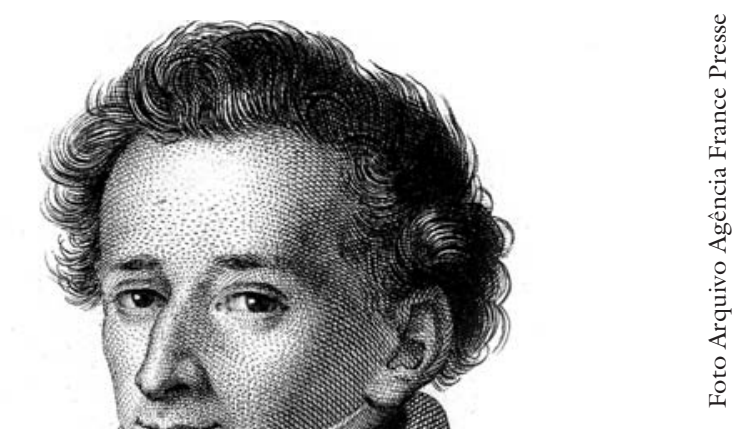
se criaram, não sobrará um
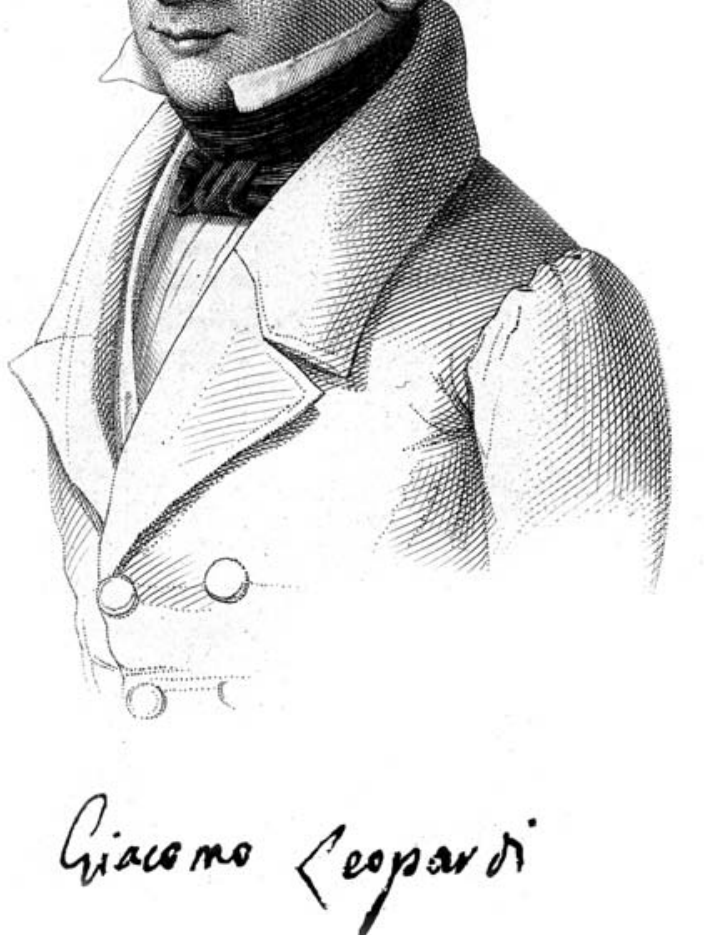

vestígio sequer; mas sim um silêncio nu, e uma quietude profunda, sublimarão o espaço infinito. Assim este mistério, magnífico e inaudito, da existência universal, antes de se declarar compreendido, se dissolverá e se perderá". Eu li e reli os versos de Leopardi desde quando era adolescente. Lembro-me ainda às vezes de que, fechado em meu quarto, relia Le ricordanze e me comovia, quase até às lágrimas, nos últimos versos dedicados à lembrança de Nerina a quem ele amou e havia morrido: “... E como um sonho/ foi a tua vida. Ali a dançar...”.

\section{$O$ ofício de ensinar}

Petro Polito - Gostaria que você lembrasse algum episódio da sua vida lecionando. Por exemplo, seu primeiro dia como professor...

Norberto Bobbio - Tenho uma particular tendência de me lembrar dos malogros no lugar dos sucessos. A minha primeira aula foi um fiasco. Eu havia me preparado bem. Devia ilustrar os itens principais do meu curso. No momento em que eu estava para ingressar na pequena classe onde haviam se juntado os poucos alunos que freqüentavam a Faculdade de Direito da Universidade de Ca- 
merino (a maior parte dos inscritos vinha das cidades vizinhas e de Roma, e não eram assíduos às aulas), ouvi uma voz por trás de mim: "Vamos todos prestar atenção à primeira aula de Bobbio". A minha autoconfiança, de repente, sumiu. Em frente a tantos colegas, inclusive mais velhos do que eu, não ousei sentar-me à cátedra, permaneci em pé, perdi na hora o fio da meada e, por mais de meia hora, não consegui retornar a falar. Um dos vexames da minha vida (tive vários!) que nunca se apagou da minha memória.

Petro Polito - Mas qual era o assunto do seu primeiro curso?

Norberto Bobbio - Desde esse primeiro curso eu planejei o ensino de filosofia do direito, como a análise dos conceitos gerais da teoria do direito, mais que como a filosofia do direito, segundo o que se pretendia na época durante a hegemonia da filosofia idealística, não a filosofia do direito propriamente dita, mas a teoria geral do direito que, desde então, dividi nos três capítulos principais: as fontes do direito, a norma jurídica e a normativa jurídica.

Petro Polito - Você ensinou filosofia do direito por tantos anos, de 1935 a 1972.

Norberto Bobbio - À medida que avançavam as minhas aulas, que prosseguiam primeiramente a Siena, depois a Pádua e, por fim, a Turim, fui aperfeiçoando a análise dos conceitos gerais da teoria do direito e dali nasceram os meus dois cursos mais conhecidos e por várias vezes reeditados Teoria della norma giuridica e Teoria dell'ordinamento giuridico que, recentemente, convergiram em um único livro intitulado Teoria generale del diritto. ${ }^{15}$ Freqüentemente eu alternava esses cursos teóricos com cursos de história do pensamento jurídico, sobre o direito natural do século XVI e do século XVII, sobre Locke, sobre Kant e, o mais adotado em outras universidades, sobre Il positivismo giuridico. ${ }^{16}$ Por uma vez somente ministrei um curso de história das idéias pacifistas e das teorias sobre a guerra em 1964-1965, ${ }^{17}$ que é a base de uma das orientações dos meus estudos e contém notícias históricas das quais amplamente me servi para o primeiro ensaio sobre o assunto Il problema della guerra e le vie della pace, apresentado em "Nuovi Argomenti" no ano de 1966. ${ }^{18}$

Petro Polito - O primeiro dos seus cursos a que eu assisti foi aquele dedicado a "La teoria delle forme di governo nella storia del pensiero politico". ${ }^{19}$ Eu diria que o ensino da filosofia da politica seguiu o mesmo método adotado para a filosofia do direito.

Norberto Bobbio - Sim, mais o método analítico que o histórico. De fato, no curso citado, minha intenção foi, sobretudo, aquela de descrever as principais tipologias das formas de governo que perduraram desde os gregos até a Idade Moderna, colocando-as em confronto entre si e ilustrando suas afinidades e diferenças. Meu último curso, no ano letivo $1978-1979,{ }^{20}$ foi dedicado a um conceito fundamental na história do pensamento político, o conceito de revolução, a começar pelo Livro V da Politica de Aristóteles, que trata das "mutações", ou seja, da passagem de um governo a outro. Esse curso, que permaneceu inédito, foi meticulosamente redigido por intermédio das anotações feitas por alguns es- 
tudantes, por iniciativa de Michelangelo Bovero, que hoje está organizando um volume dos meus ensaios de filosofia da política que se intitulará Teoria generale della politica. Sobre o tema da revolução, com explícita referência ao meu último curso, escrevi alguns anos depois um artigo, "La rivoluzione tra movimento e mutamento", publicado em Teoria Politica, ${ }^{21}$ revista fundada em 1985 por uma comissão editorial da qual eu mesmo faço parte, dirigida por Luigi Bonanate, principalmente com o propósito de apoiar as revistas tradicionais de história das doutrinas políticas e de ciência política com "uma revista que se ocupe explícita e programaticamente de teoria política" e de "favorecer e incentivar o interesse pela pesquisa neutra e apaixonada da vida política". ${ }^{22}$ Dessa elaboração nasceu a idéia de um livro dirigido à escola onde foram reunidos alguns dos meus ensaios que mais se adequavam, em sua totalidade e colocados em ordem sistemática, a ilustrar os conceitos principais da política. ${ }^{23}$

\section{Os anos do fascismo}

Petro Polito - Você exercitou o ofício de ensinar em diversos momentos da história do nosso país. Começou no tempo da ditadura...

Norberto Bobbio - Eu sempre afirmei, e aproveito esta ocasião para repetir mais uma vez, que, mesmo durante o fascismo, a Universidade pôde desfrutar de certa liberdade uma vez que fosse garantida a homenagem formal nas cerimônias públicas, nos discursos inaugurais e nas ocasiões em que o regime pretendia obediência. Quando freqüentei a universidade como estudante, no período entre 1927 e 1933, eu não me lembro de nenhum curso dos nossos professores que fosse um veículo de doutrinação. A maioria absoluta dos professores sabia muito bem distinguir a sua função de educador, da adesão, como cidadão, ao fascismo. A situação, naturalmente, foi piorando, especialmente depois do decênio, mas nas três universidades em que lecionei naqueles anos, em Camerino, Siena e em Pádua, não sofri nenhum tipo de pressão. Nos últimos anos, durante a guerra, quando o fascismo era nominalmente triunfante, mas efetivamente havia começado a morrer, dei aulas que tinham como temas os direitos naturais, o liberalismo, o socialismo, a história do liberalismo e o socialismo, temas que eram notoriamente contrários ao regime. Lembro-me ainda de que no final do ano letivo 1942-1943, pouco antes do colapso do fascismo, quando a situação era tal de não deixar dúvidas sobre o êxito da guerra, um estudante, Beppe Gerardis, um dos que tinham freqüentado assiduamente o curso e que, mais tarde, teria se transformado num membro ativo dos primeiros grupos de resistência, em nome dos companheiros, fez um breve discurso de agradecimento por aquilo que eu lhes havia ensinado.

Petro Polito - Retornando àqueles anos, Eugenio Garin lembrou o tema da "dissimulação honesta", segundo o título dos escritos de Torquato Accetto, não por acaso desenterrado por Croce em 1928. ${ }^{24}$

Norberto Bobbio - Exatamente. Eu mesmo, para mencionar esse mesmo comportamento, falei de "nicodemismo", quer dizer, da representação a que se 
submetiam os dissidentes na época das perseguições religiosas, cumprindo externamente os atos de devoção prescritos para poder continuar a sustentar, conscientemente, o próprio pensamento. Dissimulação, no sentido daquela atitude em que se finge não ser aquilo que na realidade se é (diferentemente da simulação que é o comportamento em que se finge ser aquilo que não se é), honesta, pois, em algumas circunstâncias, pressupõe-se que o fingimento seja justificado, mesmo não sendo moralmente aceitável. É supérfluo dizer em quantas ocasiões a praticamos. Uma típica manifestação de dissimulação honesta ou de nicodemismo era aquela de executar em um discurso oficial (mas não em uma aula na faculdade) algumas palavras de elogio ao duce ou ao fascismo.

Petro Polito - Pode-se considerar o juramento imposto pelo regime em 1931 aos professores universitários que, como se sabe, somente pouquissimos se recusaram, um ato de dissimulação honesta?

Norberto Bobbio - Não. As motivações que levaram a maior parte dos professores de então, e aqueles que vieram depois, e entre eles eu me incluo, a aceitar fazer o juramento são distintas: mesmo do ponto de vista religioso ou de consciência, pode-se sustentar que um juramento imposto e sancionado com penas graves, como era aquela da expulsão da atividade de ensino, não esteja vinculado ao interiore homine, e, portanto, o juramento de fidelidade ao regime comportava pura e simplesmente aquela adesão externa que já relatei. $\mathrm{O}$ mesmo se refere à inscrição forçada no Partido Nacional Fascista. Serve de exemplo um recente episódio. Por intermédio da publicação dos registros de Cesare Maria De Vecchi ${ }^{25}$ conhecida autoridade fascista, constatei que Guido Gonella, que se tornaria como qualificado representante da Democracia Cristã, o primeiro ministro da educação dos governos De Gasperi, havia solicitado, em 1934, a inscrição no partido. O responsável pela organização dos registros explica essa solicitação, inserindo-a no secular e intrigante episódio de relações entre Estado e Igreja, na Itália. A minha explicação é muito mais simples. O fato do jovem professor Guido Gonella, que não reconhece o passado antifascista e aspira a obter a filiação ao partido, pertence à modesta crônica cotidiana de prepotência imposta por um estado policialesco e não é propriamente o caso de molestar a história nacional. Gonella, estudioso da filosofia do direito, de quem eu era amigo, almejava conseguir a livre docência, um concurso para cujo acesso, aliás, como para qualquer concurso público, era necessário ser inscrito no partido. Sei, com certeza, que Gonella desejava obter a livre docência, pois, no mesmo ano, fiz requisição em companhia de Renato Treves, para conseguir esse mesmo título. De fato, no final de 1934 nos encontramos em uma sala de aula da Sapienza $a^{26}$ para o colóquio e o exame postulado. Que a caderneta do partido tenha sido para ele unicamente, como se dizia na época, a "caderneta do pão", e não o fruto de uma tardia inspiração sobre os benefícios do regime, pode-se comprovar pelo fato de que ele continuou a praticar, protegido pelo Vaticano, uma sutil, mas não inobservável, crítica ao regime, redigindo a seção Acta diurna do Osservatore Romano, umas das poucas vozes livres nos anos da guerra. 


\section{Os anos da democracia}

Petro Polito - O perído em que você lecionou durante o fascismo, porém, é breve, comparado aos longos anos em que praticou o oficio de lecionar na era da democracia. Pode fazer uma comparação entre essas duas experiências?

Norberto Bobbio - Das lembranças que falamos há pouco sobre o período em que lecionei durante o fascismo, creio poder dizer que, seja com respeito ao conteúdo seja com respeito à audiência, não me parece que tenha havido uma grande diferença. Note que a passagem do fascismo à democracia aconteceu durante os anos em que lecionava em Pádua e que as obras de referência que usei no último ano do fascismo, 1942-1943, foram igualmente utilizadas no primeiro ano após o fascismo, 1945-1946. Um dos meus primeiros alunos depois da Libertazione, Umberto Scarpelli, que me dedicou um dos seus primeiros livros, Marxismo ed esistenzialismo, lembrou-se disso com as seguintes palavras: "Portanto dizíamos". ${ }^{27}$

Pode parecer estranho, mas, se houve uma diferença, ela é exatamente o contrário do que se poderia imaginar: como eu tenho dito, pelo menos nos últimos anos, eu aplicava nas aulas um empenho ético-político que tentei evitar uma vez restabelecida a liberdade. Nos meus cursos em Turim, raramente deixei transparecer as minhas preferências ideológicas, esforcei-me sempre em demonstrar um estilo o mais asséptico possível. A ideologia democrática, de uma democracia social, era considerada um pressuposto. Era a ideologia da Constituição, nascida logo após a queda do fascismo. Do ponto de vista teórico, o meu principal inspirador foi Kelsen, que havia defendido com argumentações fortes a análise da teoria do direito, não por acaso chamada de "pura", de tal forma que deveria servir tanto a uma normativa liberal, como a americana, como a uma normativa socialista, a soviética. Permita-me recordar que, quando dei a última aula, estava presente o colega a quem me sentia intelectual e politicamente mais próximo, Alessandro Pessarin d'Entrèves, e então, mais ou menos com o mesmo temor e tremor com que me apresentei na minha primeira aula na Universidade de Camerino, citei com firmeza a célebre frase que, logo após a Primeira Guerra Mundial, em frente aos alunos que do notório professor esperavam uma orientação política, Max Weber pronunciou: "A cátedra não é nem para os demagogos nem para os profetas". ${ }^{28}$

Petro Polito - Um outro momento dificil da sua vida de educador, que o empenhou também como pai, foi o 68, durante o qual não foi fácil, penso eu, manter esse distanciamento e permanecer impassivel.

Norberto Bobbio - Meu filho ${ }^{29}$ era na época o secretário da assembléia universitária (o "parlamento dos estudantes") como representante da Ugi, que agrupava tanto os socialistas como os comunistas. Os documentos do assim chamado "poder estudantil" oposto ao "poder dos barões" eram assinados pelo meu filho. Como você pode imaginar, por muitas vezes, encontrei-me em dificuldade, especialmente nas reuniões da faculdade. Eu já falei daquilo que chamei um "conflito familiar" na Autobiografia. 
Petro Polito - Como era sua relação com os estudantes contestadores?

Norberto Bobbio - Diante da "contestazione", como então era chamada, sempre me dividi entre consenso e dissenso. Consenso, porque algumas solicitações dos estudantes, especialmente a de um envolvimento mais ativo por parte dos professores na realização das suas funções e um distanciamento menor por parte dos destinatários naturais dos seus ensinamentos, eram exigências não somente legítimas, mas, confrontando a nossa universidade com as americanas que eu havia visitado naqueles anos, que tornaram necessárias; dissenso, com relação ao modo em que essas exigências eram feitas; assembléias tumultuosas em que se votava por aclamação, não se deixavam falar os dissidentes, ameaçava-se usar a força do número contra as minorias dissidentes, as classes onde se reuniam os estudantes não-contestadores eram invadidas pela força e as aulas eram interrompidas muitas vezes tomando o lugar dos professores e os impedindo de falar. Aqueles que, como eu, procuravam o diálogo participando por vezes das assembléias, logo perceberam que o diálogo não era possível. Lembro-me de uma dessas assembléias em que fui como convidado. Quando pediu a palavra o representante do Partido Republicano, que é um partido notoriamente antifascista, mas não de esquerda, não o deixaram falar. Levantei-me e deixei o salão. Além disso, era inaceitável a pretensão de não seguir as matérias das aulas da maneira como vinham apresentadas nas agendas dos alunos, mas sim organizar cursos chamados de autoconduzidos, quando se tratava de assuntos como a Guerra do Vietnã, o imperialismo americano, a revolução chinesa, ou quando eram interrogados durante as avaliações. Em nome do princípio de um igualitarismo abstrato que não deveria fazer distinções entre ricos e pobres, entre capazes e medíocres ou até mesmo péssimos, era também absurda a presunção que, quando interpelados nos exames, todos deveriam obter a mesma nota.

Petro Polito - Causa impacto a consonáncia entre o seu juizo e o de Garin que, após ter afirmado que a revolta estudantil de 68 lhe pareceu a necessária conclusão de uma política errada e culpada, observa: "O Sessantotto não apenas não melhorou em nada a situação, como piorou-a ainda mais, carregando-a inclusive de ideologismos abstratos". E acrescenta: "que eu me lembre, foi uma das circunstâncias mais melancólicas”. 30

Norberto Bobbio - Não posso dizer que ele esteja errado. Tanto barulho para nada. Uma chama que logo se apagou, deixando talvez somente um punhado de cinzas. Não obstante o entusiasmo com que o poder estudantil, como então era chamado e que nos melhores estudantes certamente era sincero, reivindicava uma reforma radical da universidade, uma universidade mais livre em que as relações entre professores e alunos originassem uma verdadeira e própria comunhão de intenções e de vida, as coisas não mudaram muito; talvez, tenham até piorado. A única grande reforma que surgiu após a "contestação" foi a da "liberalização das admissões" que permitiu a inscrição em todas as faculdades mesmo os alunos das escolas técnicas que até então não podiam se matricular em faculdades que não fossem de Economia e Comércio e, iniciando já naquele 
ano, na nova Faculdade de Sociologia de Trento. Era uma inovação importante, mas foi, como acontece freqüentemente no nosso país, muito mal aplicada, quer dizer, sem condições e sem limitações. Lembro-me dessa reforma porque também meu programa de curso, em parte, foi alterado. Como conseqüência da liberalização, inscreveram-se na faculdade de jurisprudência centenas e centenas de diplomados, ${ }^{31}$ inclusive mais idosos, que podiam, finamente, ingressar na universidade. Naturalmente, tratava-se de estudantes que já trabalhavam e uma laurea poderia melhorar suas carreias. Instituí para eles um curso aos sábados pela manhã. Li página por página e analisei o Contrato social de Rousseau, com o intuito de encaminhá-los à "disciplina dos clássicos" que sempre considerei um momento fundamental da minha didática universitária.

Petro Polito - Gostaria que você se detivesse um pouco mais no que, me parece, tenha sido a característica da sua doutrina escolar, isto é, favorecer o encontro e o confronto dos seus estudantes com os autores, especialmente os clássicos. Qual é, em sua opinião, o dever principal do professor?

Norberto Bobbio - Eu sempre considerei que a principal virtude do professor é a clareza na exposição dos conceitos fundamentais e na organização discursiva das suas definições. Que eu a tenha alcançado, não sei. Os diversos conteúdos dos meus cursos foram continuamente adotados em outras universidades. Sempre dei muita importância ao que chamei "disciplina dos clássicos": ler e comentar os grandes textos do pensamento político e jurídico. Não separar a teoria da história; confrontar a teoria na história e utilizar a história para ilustrar a teoria. Do abstrato ao concreto e do concreto ao abstrato. A teoria sem história é vazia, a história sem teoria é cega. Um outro mérito que me concedo, e me desculpe a vaidade, é aquele de nunca ter me permitido cair na rotina. É inútil dizer, uma prática constante do professor é aquela de repetir, no ano seguinte, exatamente o que havia dito no ano anterior. Acontece regularmente que se diga de um professor que é inútil assistir às suas aulas, pois tudo aquilo que está dizendo já foi dito, escrito e impresso. Não estou dizendo, de forma alguma, ter feito a cada ano um novo curso. Mas ainda hoje, por aí, se encontram muitos textos dos meus cursos.

Petro Polito - Li recentemente, em uma breve entrevista autobiográfica, uma frase de Toni Negri que diz respeito a você e àqueles que ele considera "os verdadeiros grandes mestres que me ensinaram coisas. Como Bobbio, como Guarino, como Chabod, como o reitor de Pádua Opocher... E mais tarde, em Paris, como Foucault, como Deleuze e Guattari”. ${ }^{2}$

Norberto Bobbio - Eu conheci Negri jovem filósofo do direito, aluno do meu assistente nos meus últimos anos em Pádua, e depois sucessor, Enrico Opocher. Ele fez parte dos jovens estudiosos que eu havia selecionado para um seminário de teoria do direito com o conhecido filósofo do direito inglês Herbert Hart que aconteceu na villa Serbelloni di Bellagio em setembro de 1960. Nos primeiros anos do seu encarceramento, mantivemos uma amigável correspondência. Desde então, não o vi mais. 


\section{O ofício de escrever}

Petro Polito - Da entrevista autobiográfica, já comentada, de Gnoli e Volpi com Jünger, extraio uma bela definição da tarefa do escritor: "O verdadeiro escritor, como a autêntica riqueza, se reconbece não pelos tesouros que possui, mas pela sua capacidade de tornar preciosas as coisas que toca. Portanto, ele é como uma luz que, mesmo sendo invisivel em sua forma, aquece e torna visivel o mundo". De fato, "a potência de um escritor - segundo o filósofo alemão - está imersa nisso: no duvidar da confusão e não se deixar levar pela atmosfera apocalíptica". ${ }^{3}$ O que pensa disso?

Norberto Bobbio - É difícil, para mim, comentar essa concepção de Jünger porque, como já lhe disse, nunca me senti um "verdadeiro escritor". Uma coisa é escrever, outra é ser escritor. Nunca pensei possuir a capacidade de "tornar preciosas as coisas que toco". Essa virtude pertence, mais que ao escritor no sentido geral da palavra, ao poeta. A minha veia poética extinguiu-se após alguns anos de dedicação. É raro alguém que, quando adulto, tenha se ocupado de disciplinas filosóficas, históricas, em geral humanísticas, não tenha publicado durante a juventude um pequeno volume de versos; ou não tenha se apresentado aos amigos lendo as próprias poesias. Como se deve definir a veia poética eu não sei. Mas há os que a têm, os que não a têm, e os que a tiveram por um breve período de suas vidas que é, de certo, aquele da juventude.

Reconheço-me em parte, se assim for e se eu entendi bem o sentido da frase, na virtude de evitar a "confusão" e de não me abandonar à "atmosfera apocalíptica". Os escritores que amo são aqueles que amam as idéias claras e determinadas e as exprimem com ordem. Dos escritores obscuros prefiro não me ocupar, não porque considere que não sejam talvez mais importantes do que os claros, mas talvez porque eu não os entenda ou me custe muito esforço entendê-los. Sou até capaz de admirá-los, mas observo-os de longe. Se por "atmosfera apocalíptica" se entender o fantasiar sobre o próprio futuro e sobre o da humanidade, eu o recuso, não sei se por falta de fantasia ou por reserva.

Petro Polito - Demos algum exemplo de escritor claro e determinado.

Norberto Bobbio - Não tenho nenhuma dúvida em propor o nome de Thomas Hobbes. Atendo-me a uma tese de laurea sobre a minha interpretação a respeito do grande filósofo inglês, acabei por redescobrir uma frase minha de mais de quarenta anos atrás: "Hobbes é um dos autores que mais estudei e com maior interesse e empenho. Satisfaz-me porque observa a realidade humana com o olhar frio e seguro de Maquiavel, mas escreve e reflete como Descartes". ${ }^{34}$

Petro Polito - Diria que Bobbio pertence à classe dos escritores claros...

Norberto Bobbio - Já me aconteceu de admitir que "entre os elogios, o mais prazeroso que algumas vezes me é dirigido, é aquele da clareza, mesmo a clareza não sendo sempre uma qualidade e a obscuridade nem sempre um defeito. Sei bem que existe também uma clareza enganadora". O próprio Hobbes foi considerado réu de "confusing clarity". ${ }^{35}$ 


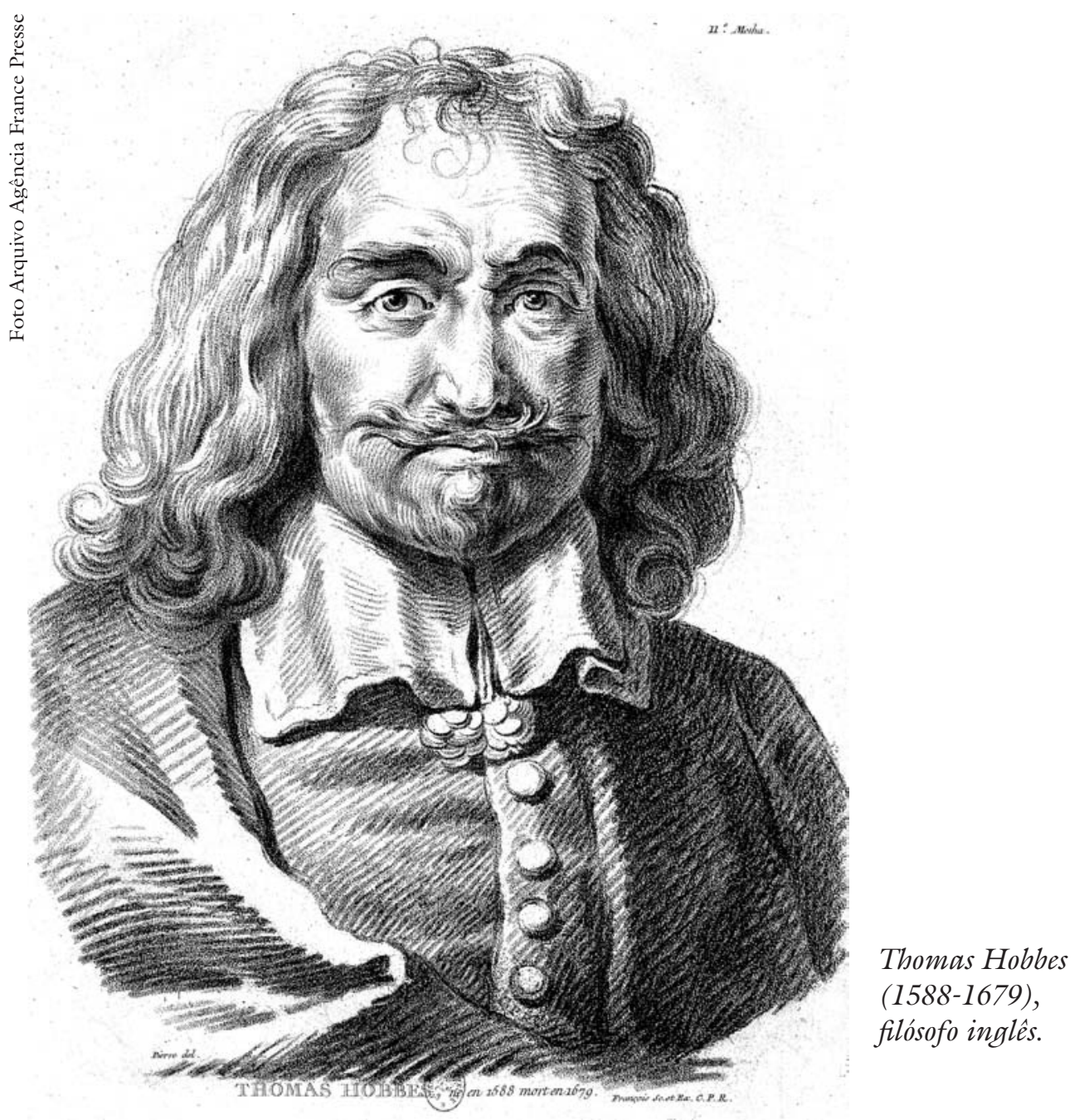

Petro Polito - Como nasce a sua escritura? Você acabou de lembrar que não mantém um diário, porém creio que você escreva, praticamente, todos os dias.

Norberto Bobbio - Sim, é verdade, escrevo todos os dias, talvez por necessidade ou por obrigação. Cartas, como já lhe disse, apontamentos sobre os livros que leio e reflexões sobre as obras que estou preparando. Reúno-os em breve anotações que chamo de "foglietti" que transbordam de novas e velhas gavetas. ${ }^{36}$ Mas, não obstante o longo e ininterrupto exercício, não sou aquele que escreve com fluidez. Dificilmente, se não nas cartas que agora eu dito, a primeira redação me agrada. Mesmo que nesses últimos anos eu tenha escrito também bastante para jornais, sinto-me em dificuldade quando me pedem um artigo de um dia para o outro, exceto no caso de morte repentina de um personagem de quem não posso recusar o necrológio. Os diretores do La Stampa já sabem que não me devem nunca solicitar algum comentário, como se diz, " $a$ caldo" sobre os fatos do dia. Mesmo as minhas entrevistas precisam ser revistas e corrigidas. Parecem conversas, mas na realidade são conversas escritas e reescritas. 
Petro Polito - Quais as páginas que você escreveu e se sente mais apegado, as que mais você aprecia?

Norberto Bobbio - Entre as páginas que me estão mais afeiçoadas, encontram-se as dos meus livros de testemunho, pois são páginas em que exprimo os mais fortes laços afetivos que tive com as pessoas, como escrevi, que "me ajudaram a viver". Você os conhece bem, são Italia civile, Maestri e compagni, Italia fedele (este último exclusivamente sobre Gobetti e o seu mundo). Não é necessário que lhe diga que está em preparação um quarto livro que será provavelmente intitulado Amici ed allievi. ${ }^{37}$

Petro Polito - Quer saber quais os seus livros mais significativos para a minha formação?

Norberto Bobbio - Sim, interessa-me.

Petro Polito - A primeira vez que ouvi seu nome foi no terceiro ano do liceo, em 1975, na minha cidade natal. Lembro-me de que numa manhã o professor de filosofia nos falou de Politica e cultura. Foi o seu primeiro livro que li, no ano seguinte, em Turim. Mas o livro da minha geração, lançado em 1976, quando eu tinba vinte anos e que li por mais de uma vez naqueles anos não fáceis, foi Quale socialismo?. ${ }^{38}$ É um livro que, em minha opinião, deveria ser mais uma vez reproposto, pois fornece um fundamento sólido a uma visão liberal do socialismo, e não perdeu nada da sua força e atualidade.

Norberto Bobbio - O que você me diz não me surpreende, embora eu nunca tivesse pensado nisso. Para a sua geração, esse livro significa a continuação do debate sobre o comunismo, mas em uma nova fase, que não é mais aquela do confronto entre tradição liberal e o pensamento comunista, mas sim aquela no interior do mundo da esquerda entre socialismo autoritário e socialismo democrático. Tratava-se de redescobrir, ou melhor, reavaliar aquela corrente de socialismo que, embora tenha existido em nosso passado recente, foi sufocada. De um lado, pela hegemonia de um marxismo enrijecido, transformado em ideologia de um estado totalitário; de outro, por um esquerdismo revolucionário que colocava em perigo a nossa frágil democracia, em que há somente espaço para uma esquerda reformadora. Era um livro que estava destinado a ser criticado por partes opostas, por aqueles que não haviam renunciado ao socialismo como transformação radical da sociedade e por aqueles que se abandonaram em um socialismo acomodador que, para romper qualquer relação com os comunistas e com as tradições do pensamento socialista, não podiam mais suportar o "catechismo dei nonni".

Petro Polito - Você não pode negar, porém, que se pode falar de um inegável sucesso a propósito da sua obra. Um sucesso que se expressa tanto na publicação de novos livros quanto nas numerosas traduções (não faz muito tempo a nossa amiga Santina Mobiglia, que acompanhou a difusão das suas obras no exterior, trouxe-nos a primeira cópia da tradução para o árabe do Elogio della mitezza). Perguntome, de fato, se você tem consciência de que escreveu milhares e milhares de páginas. O que é e como se mede o sucesso para um escritor? 


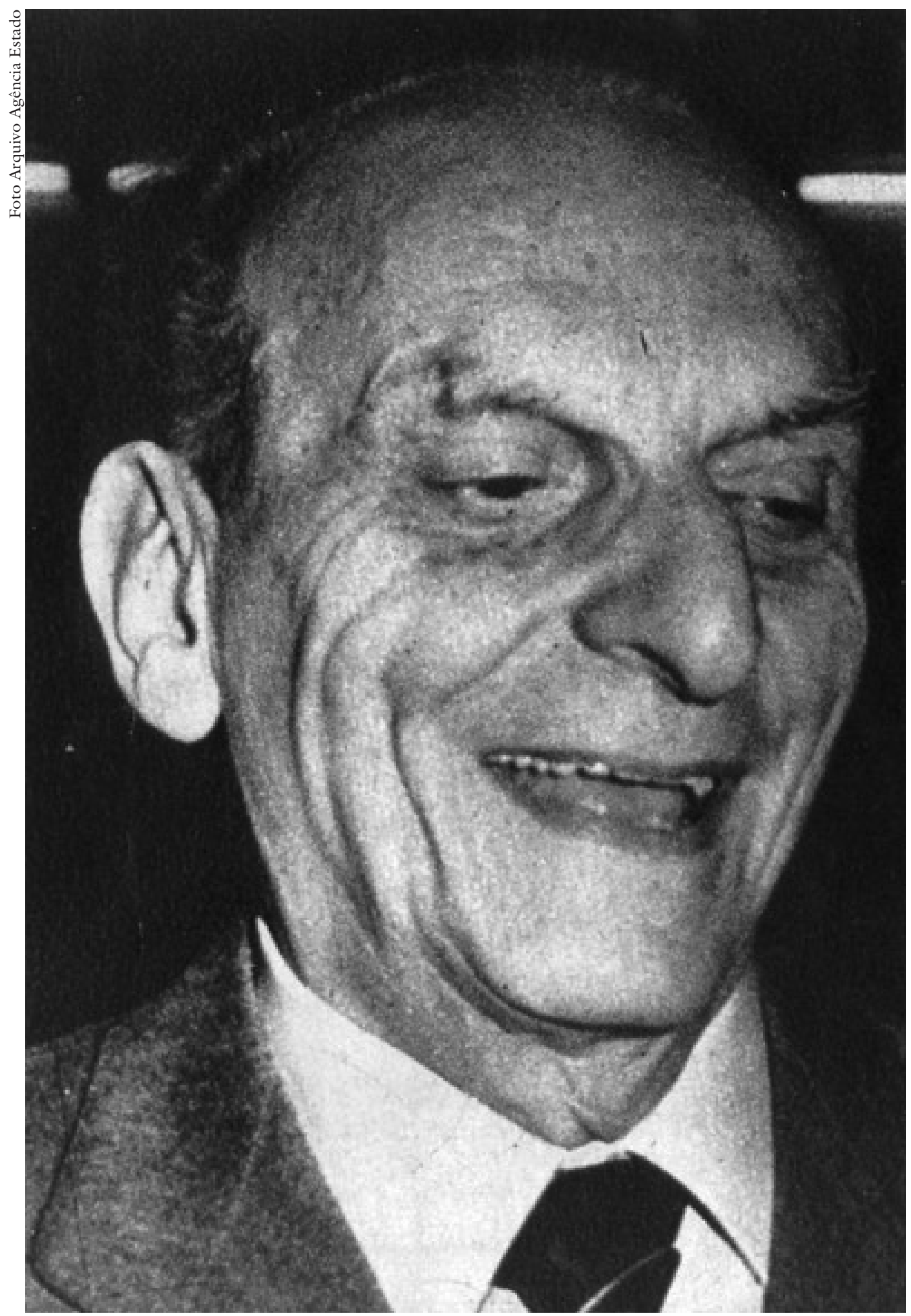

Norberto Bobbio (1909-2004) visiton o Brasil pela primeira vez em 1982 e tem várias obras traduzidos para o português, entre elas Teoria da Norma Jurídica (2005), Dicionário de Política, 2 volumes (2004), (com Nicola Matteucci e Gianfranco Pasquino) Era dos Direitos (2004). 
Norberto Bobbio - Não existe uma regra, como é fácil de entender. Leia qualquer uma das listas dos best-sellers publicadas em vários jornais e você vai concluir. Romances de grandes escritores junto com porcarias. Autores surpreendentemente afortunados com autores de outra forma surpreendentemente desconsiderados, pelo menos sob o seu juízo pessoal. Se eu refletir, como costuma me acontecer, sobre o maior ou menor sucesso dos meus livros, me encontro sempre à frente da mesma incógnita: o meu livro hoje mais citado e lembrado é Politica e cultura, lançado pela Einaudi em 1955. Quando saiu não teve uma grande difusão, e o que comprova é que uma nova edição foi lançada praticamente vinte anos depois. É difícil, para mim, entender como esse meu livro me rendeu mais apreciações e cartas de consenso. Embora, na época, certamente, não tenha sido muito lido. Bem mais rápida foi a difusão do meu Profilo ideologico del Novecento,${ }^{39}$ que eu havia escrito, no início, apenas como o capítulo de uma grande história da literatura italiana em vários volumes. Não poderia nunca imaginar que um dos meus livros mais solicitados fosse o Elogio della mitezza,${ }^{40}$ que você lembrou e conhece bem, como foi sua a idéia de uma coleção de escritos vários colocados juntos, mas em nada homogêneos. Eu esperava certo sucesso do livro em que recolhi quase todos os escritos sobre o tema dos intelectuais, Il dubbio e la scelta, ${ }^{41}$ lançado em 1993, tema sobre o qual retornei em diversas ocasiões. No entanto, quase ninguém o comentou. Morreu na primeira edição, não o vejo mais citado nos tantos livros que se lançaram esses anos, mesmo na Itália, sobre esse assunto. O meu único livro que teve um grande sucesso é o pamphlet sobre esquerda e direita, lançado em 1994, com várias impressões, até recentemente com uma nova introdução e traduzido numa dúzia de línguas. ${ }^{42}$ Qual seria a razão do sucesso, isso é difícil explicar, mas nem eu nem o editor conseguimos desvendar. A experiência que tive com meus livros é a melhor prova de certa casualidade do sucesso de um livro e, portanto, da sua imprevisibilidade.

Petro Polito - O tema do sucesso é estritamente ligado, eu diria, ao ofício de viver. Não sei se outros leitores tenham notado a reminiscência leopardiana que se sente na escolba de encabeçar o prefácio de De senectute com as palavras A me stesso. Gostaria de retomar esse texto porque, diferentemente de outros escritos autobiográficos, em que prevalece o equilibrio intelectual, nesse nota-se mais a tendência a um equilíbrio pessoal. ${ }^{43}$ Escrevia: "Ter dúvidas sobre mim mesmo, e o desagrado das metas alcançadas, muitas delas inesperados, imprevistas, sempre se originaram, se não precisamente da convição, então da suspeita que a facilidade com que consegui percorrer a minha estrada, para muitos dos meus coetâneos inacessiveis, tenha sido mais pela boa sorte e a condescendência dos outros do que pelas minhas virtudes, se não até mesmo por alguns dos meus defeitos vitalmente úteis, como aquele de saber me retirar em tempo, antes de ter cumprido o último passo, o de maior risco (um assunto do qual poderia escrever um pequeno ensaio que intitularia Del mio moderatismo)".44

Norberto Bobbio - Você bem se lembra, e já disse uma vez, que se podem distinguir os homens satisfeitos por si próprios daqueles nunca contentes. Não 
é o caso de repeti-lo, pois tornou-se uma espécie de refrão que repito nas mais diferentes ocasiões. Pertenço à segunda categoria. Se você me perguntar mais alguma coisa, me deixará em apuros. Não há nada mais difícil do que retirar todos os véus que cobrem em você o fundo que permanece obscuro da sua natureza. Nada de mais difícil e de mais desagradável. No que se refere a mim, sempre tive muita autocrítica. Sempre disse, mesmo nesta entrevista, da lição dos clássicos. A primeira e mais duradoura lição que deles aprendi é aquela da humildade, de não se deixar subir à cabeça, de não perder o sentido das proporções. Numa visão laica da vida (não laicista, porque o laicismo é uma igreja como todas as outras, com os seus dogmas e anátemas), numa visão, isto é, na qual o lampião da razão é somente aquele que podemos dispor para iluminar as sombras em que nos imergimos, não há lugar para certezas absolutas, a nossa condição permanente é aquela da dúvida metódica.

Petro Polito - Ainda de A me stesso extraio uma frase sobre o oficio de viver: "creio que no fundo da minha insegurança, que gera ansiedade e favorece uma irresistivel vocação a catastrofismo, exista a dificuldade que tive que superar desde a adolescência para aprender a arte de viver, agravada pela conviç̧ão de não tê-la nunca aprendido bem, apesar da prática de excepcional duração". ${ }^{5}$

Norberto Bobbio - Agora é muito tarde para aprender. Mas não está longe o tempo em que, mesmo se a tivesse completamente assimilado, não me serviria mais.

Notas

l N. BOBBIO-P. POLITO. Dialogo su una vita di studi. Nuova Antologia, n.2200, p.31-63, out.-dez. 1996. Esse novo diálogo foi obtido nos meses de maio, junho e julho de 1999.

2 A. GNOLI-F. VOLPI. I prossimi titani. Conversazione con Ernst Jünger. Milão: Adelphi, 1997. p.119-20.

3 Refere-se à guerra dos Bálcãs durante a qual Bobbio interveio algumas vezes: "L'America ricorda la lezione del Vietnam?". Bobbio: mezzi spaventosi, tanto dolore, poi il ritiro, entrevista feita por A. Papuzzi, La Stampa, 28 de março, p.3; Bobbio: indipendenza, unica soluzione. "È lo sbocco inevitabile dell'intervento alleato", entrevista feita por A. Papuzzi, La Stampa, 18 de abril, p.3; Uno così deve essere eliminato dalla faccia della terra. Il durissimo giudizio del filosofo torinese che però si domanda se la guerra sarà "efficace", colóquio com Norberto Bobbio de Manuela Pasquini, in Le prove del genocidio, incluído no n.59, de Liberal, 22 de abril de 1999, p.4-5; "Questa guerra somiglia tanto a una guerra santa". Norberto Bobbio retorna ao conflito em Kosovo: "Fuori dalle regole, ma è uma scelta obbligata", entrevista feita por Giancarlo Bosetti, l'Unità, 25 de abril, p.5; "Non siate prigionieri dell'antiamericanismo", l'Unità, 30 de abril, p.l e 7; "Guerra nei Balcani e pace ideale", La Stampa, 10 de maio, p.1 e 8; "Ma hanno già bombardato tutto". Bobbio: sta fallendo la prima guerra dei diritti. Il filosofo giudica due mesi di conflitto che dividono le nostre coscienze, entrevista feita por A. Papuzzi, La Stampa, 16 de maio, p.5; "La guerra dei diritti umani sta fallendo". Le riflessioni di Norberto Bobbio, "Gli intellettuali deprecano ma non contano", entrevista feita por G. Bosetti, L'Unità, 16 de maio, p.6. 
4 N. BOBBIO. O terceiro ausente. Ensaios e discursos sobre a paz e a guerra. Organizado por P. Polito. Turim: Sonda, 1989. p.163.

5 N. BOBBIO. O terceiro ausente, op. cit., p.186.

6 N. BOBBIO. De senectute e outros escritos autobiográficos. Turim: Einaudi, 1996. p.10.

7 N. BOBBIO. Politica e cultura. Turim: Einaudi, 1955. p.10.

8 U. CAMPAGNOLO. Petit dictionnaire pour une politique de la culture. Neuchâtel: Éditions de la Baconnière, 1969. p.43-7.

9 N. BOBBIO. Avant-propos. Comprendre, n.47-48, p.3, 1983-1984.

10 Liceo Clássico, equivalente no Brasil ao Ensino Médio com ênfase em Ciências Humanas. (N. T.)

11 "Thomas Mann, il mio scrittore politico", entrevista com Norberto Bobbio de Beniamino Placido, in "L'Indice dei libri del mese", n.8, setembro de 1995, p.19. Na rubrica: "Libri della vita". O episódio é lembrado também na Autobiografia, cit. p.7-8.

12 É o momento em que o jovem se torna "mais maduro" e, na Itália, é quando termina a escola superior, a que antecede o ingresso na faculdade e obtém o diploma di stato. Por exemplo, ao fim do Liceo Classico, conquista-se o diploma de maturità clássica, ao fim do Liceo Scientifico, diploma de maturità scientifica e assim para as demais áreas. (N. T.)

13 Os estudos sobre Marx foram organizados no volume Né com Marx né contro Marx, por Carlo Violi, Editori Riuniti, Roma, 1997.

14 Inclusive na Autobiografia, recorda que o escritor "lido quase que ininterruptamente em diversas épocas da minha vida, mesmo como escritor político, foi Thomas Mann" (p.9). Acrescenta de ter "lido muito Balzac" e de ter concluído aqueles, consideradas "na época, leituras obrigatórias, quando agora, me parece, não são mais -, de Stendhal a Flaubert, de Dostoiévski a Tolstoi” (p.8-9).

15 Teoria della norma giuridica. Turim: Giappichelli, 1958, p.245; Teoria dell'ordinamento giuridico, Turim: Giappichelli, 1960, p.218; Teoria generale del diritto. Turim: Giappichelli, 1993, p.X-297. No Prefácio a Teoria generale del diritto, lê-se que os dois cursos constituem "a síntese e, de certo modo, a conclusão do período de estudos por mim dedicado prevalentemente à teoria do direito, durante aproximadamente vinte anos que se estendem desde os primeiros anos do pós-guerra, nos quais concluí meu aperfeiçoamento comentando alguns entre os mais importantes tratados de teoria geral do direito e corajosamente tomando as defesas de Kelsen contra alguns de seus críticos até, por assim dizer, o famigerado '68'” (p.VI).

16 Diritto e stato nel pensiero di Emanuele Kant, Lições reunidas pelo estudante Gianni Scioratti. Turim: Giappichelli, 1957, p.285; Locke e il diritto naturale. Turim: Giappichelli, 1963, p.287; Il positivismo giuridico, Lições de filosofia do direito reunidas pelo Dr. Nello Morra. Turim: Editora Cooperativa Livraria Universitária, 1961, p.324, 2.ed. acrescida em 1979, última ed., com uma premissa à nova edição de F. D’Agostino, 1996.

17 Il problema della guerra e le vie della pace, Lições de filosofia do direito ministradas pelo Prof. Norberto Bobbio no ano letivo 1964-1965, reunidas pelas alunas Nadia Betti e Marina Vaciago. Turim: Editora Cooperativa Livraria Universitária, 1965, p.276.

18 Depois, acrescentado ao volume homônimo Il problema della guerra e le vie della pace, Bolonha: O Moinho, 1979, alcançou, em 1997, a quarta edição. 
19 La teoria delle forme di governo nella storia del pensiero politico, ano letivo 1975-1976, curso de filosofia política. Turim: Giappichelli, 1976, p.212. Ver I corsi di Filosofia della politica, de M. Bovero, na Universidade de Turim. Departamento de Estudos Políticos, A Norberto Bobbio, La facoltà di scienze politiche, Turim, 1986, p.55-66.

$20 \mathrm{Na}$ Itália, como na maioria dos países europeus de clima temperado, o ano letivo inicia no mês de setembro, após o verão; logo, seu período de duração prossegue até julho do ano seguinte. (N. T.)

21 O artigo abre o número monográfico da revista Sulla Rivoluzione, "Teoria politica", ano V, n.2-3, p.3-21, 1989.

22 L. BONANATE. Il programma di “Teoria politica”. In: “Teoria politica”, a. I, n.1, p.3 e $4,1985$.

23 N. BOBBIO. Elementi di politica. Antologia. Organizado por P. POLITO. Milão: Einaudi Escola, 1998.

24 E. GARIN. Intervista sull'intellettuale. Organização de M. Ajello. Roma-Bari: Laterza, 1997. p.27.

25 C. MARIA DE VECCHI DI VAL CISMON. Tra Papa, Duce e Re. Organizado por S. Setta. Roma: Jouvene, 1998.

26 Denominação de antigas universidades; sobrevive no nome da Universidade de Roma. (N. T.)

27 N. BOBBIO. Autobiografia, cit., p.78.

28 A frase se encontra na famosa conferência La scienza come professione (1919), agora em Il lavoro intelletuale come professione. Nota introdutória de D. Cantimori. Tradução de A. Giolitti, Turim: Einaudi, 1948. Primeira edição em "Nue Nouva serie", 1976, p.29. No dia 16 de maio de 1979, Bobbio ministra sua última aula como titular da cátedra de Filosofia da política. Nos anos seguintes proferiu numerosos seminários para os estudantes de filosofia da política e, no ano letivo de 1981-1982, lecionou como suplente o curso de Ciência da Política dedicando as aulas ao "Concetto di governo". No período 1979-1999 foi um dos principais promotores e organizadores do Seminario "Etica e politica" do Centro de Estudos Piero Gobetti. Algumas de suas aulas foram reunidas no fascículo Seminario "Etica e politica" (1980-1988). Lezioni di Norberto Bobbio, con una appendice di materiali, Centro de Estudos Piero Gobetti, Turim, 1989 (aulas reunidas sob a forma de fascículos em uma edição provisória sem revisão por parte do autor, promovida pelo Centro Gobetti pelos oitenta anos de seu presidente e impressa em dez cópias numeradas destinadas ao autor e ao arquivo do Centro de Estudos.

29 Luigi Bobbio, autor de Storia di Lotta continua, Milão: Feltrinelli, 1976.

30 E. GARIN. Intervista sull'inteletuale, p.66-67, 68 e 69.

$31 \mathrm{O}$ autor se refere aos diplomados na escola superior. Após o término da faculdade, o estudante recebe então certificado de Laurea, do latim, "coroa de louros". (N. T.)

32 La sovversione, colóquio de Annamaria Guadagni com Toni Negri, Liberal, Roma: Atlantide Editorial, 1999, p.63.

33 A. GNOLI - F. VOLPI, I prossimi titani. Conversazione con Ernst Jünger, cit., p.58.

34 De uma carta de 14 de agosto de 1951 a Giovanni Battista Angioletti, na época diretor do Terceiro Programa RAI, em que Bobbio aceita de fazer um comentário radiofônico de Leviatano, posteriormente transmitido em 19 de dezembro do mesmo ano. 
35 N. BOBBIO. De senectute, cit., p.145. A expressão é de R. Pennock, Hobbes's Confusing Clarity. The Case of Liberty, in K. C. Brown (Org.) Hobbes Studies, Balckwell Oxford, 1965.

36 Lê-se no início de De senectute: "Tenho que me contentar com um monte de folhetos escritos nas mais diversas ocasiões, muitas vezes sem data, reunidos em pequenas pastas sem nenhuma ordem preestabelecida, onde transcrevi um trecho para citar, ou o título de um livro, ou onde fixei uma idéia que tenha me ocorrido, lendo, passeando, fantasiando. Freqüentemente são diálogos imaginários com interlocutores reais, escritores, jornalistas, companhias ocasionais. Neles manifesto sentimentos e ressentimentos, simpatias e antipatias, intolerâncias, pequenas indagações e grandes indignações, mas também comentários e fatos do dia, breves reflexões para dissipar uma dúvida, argumentos pró e contra uma tese controversa, rascunhos de escritos futuros. Repetidamente esses folhetos contêm anotações autobiográficas, estendidas sobre o papel não tanto para passá-las aos próximos eventos memoráveis, quanto para dar vazão a um estado de ânimo ansioso, refletir sobre um erro cometido com a intenção de não o repetir, tomar nota de um defeito com a intenção de me livrar dele, porém consciente e capaz de confessá-lo, pelo menos, a mim mesmo" (p.3).

37 Os livros de testemunho de Bobbio são publicados pela Editora Passigli, Florença.

38 N. BOBBIO. Quale socialismo. Discussione di un'alternativa. Turim: Einaudi, 1976.

39 Na última edição italiana Profilo ideologico del Novecento (Milão: Editora Grazanti, 1990), foi preparada uma edição americana: Ideological Profile of Twentieth-Century Italy, Translated by Lydia G. Cochrane; Foreword to the Series by Charles S. Maier, Foreword by Massimo L. Salvatori, Preface by Norberto Bobbio, Princeton University Press, Princeton (New Jersey), 1995, Translator’s Note: Bruno Bongiovanni. Com relação à edição italiana, a edição americana apresenta alguns anexos.

40 N. BOBBIO. Elogio della mitezza e altri scritti morali. Milão: Pratiche, 1998. Pela história do texto lançado primeiramente como anexo de "Linea d'ombra" 1993 e como volume junto às edições da revista em 1994, ver p.209-11.

41 N. BOBBIO. Il dubbio e la scelta. Intelettuali e potere nella società contemporanea. Roma: La Nuova Italia Scientifica, 1993.

42 N. BOBBIO. Destra e sinistra. Ragioni e significati di una distinzione politica. Roma: Donzelli, Nuova edizione 1999. As edições precedentes são de 1994 e de 1995.

43 N. BOBBIO. A me stesso, in De senectute, cit., p.3-14. Devem ser vistos também: Congedo, Autobiografia intellettuale, Um bilancio, Ivi, p.95-108; p.121-41; 163-74; inclusive o último capítulo da Autobiografia, também intitulado, Congedo, p.247-63.

44 N. BOBBIO. A me stesso, in De senectute, cit., p.6. Sobre moderatismo, ver N. BOBBIO, "Voi estremisti, io moderato, "il manifesto", 28 de maio de 1991 (Entrevista feita por L. Campetti, lançada pelos vinte anos do cotidiano) e N. BOBBIO - P. POLITO, Dialogo su una vita di studi, cit., p.57-8.

45 N. BOBBIO. A me stesso, in De senectute, cit., p.7.

A íntegra da entrevista por ocasião dos noventa anos de Norberto Bobbio foi publicada em Estratti Della Nuova Antologia (fasc. 2211, julho-setembro 1999), da Fundazione Spadolini Nuova Antologia, Itália.

Tradução de Marcos Romiti. O original em italiano encontra-se à disposição do leitor no IEA-USP para eventual consulta. 